Institute of $\mathbf{F}_{\text {ood and }} \mathbf{A}_{\text {gricultural }} \mathbf{S}_{\text {ciences }}$

\title{
Forage Soybeans for Grazing, Hay and Silage ${ }^{1}$
}

\author{
A.R. Blount, D.L. Wright, R.K. Sprenkel, T.D. Hewitt, C.K. Hiebsch, and R.O. Myer² \\ Livestock producers need a high-protein summer

\section{Nutritional Quality} forage. Forage soybeans fit well in a production system following small grains or early planted corn.

Soybeans have a long history as a nutritious hay and silage crop. Prior to World War II, the principal use of soybeans was as forage. By the early 1940s, soybeans were harvested at various stages of growth, cured and fed as high protein hay, which was considered to be similar in nutritional value to alfalfa. When oil seed values climbed in the 1960s and 1970s, soybean production shifted almost exclusively to seed types and away from forage types. With the current low value of soybeans grown for oil, forage soybeans are making a comeback. Soybean plants may be grazed, or harvested from the flowering stage to near maturity for use as high quality hay. Soybeans may also be grown as a silage crop in pure culture or intercropped with corn or sorghum. Using soybeans for forage, rather than grain is also economically feasible given the current relative values.

During the 1920s and 1930s, forage soybean production--and the subsequent nutritional value of hay and silage-- were investigated extensively. These earlier trials concluded that soybeans should be drilled at high populations ( 1.5 to $2.0 \mathrm{bu} / \mathrm{acre}$ of average size seed) to obtain small stem diameters. A high plant population would promote

thinner-stemmed soybeans, which would be easier to condition to ensure proper curing. The stem is the least desirable plant component, since it is considered to be coarse and fibrous. Soybeans may be harvested for hay at any stage of growth. Because summer rainfall patterns in Florida are erratic, conditioning the stems may be necessary to cure hay in a timely manner.

Unlike most legume crops used for hay, both foliage and pods provide digestible protein. The soybean plant, when harvested just prior to leaf yellowing at maturity, has pods that are high in protein and oil. The quality of forage soybeans varies depending on the variety, stage of growth, age, and harvesting losses. Contrary to other forage legumes, the protein percent and the quantity of protein and

1. This document is SS-AGR-180, one of a series of the Agronomy Department, Florida Cooperative Extension Service, Institute of Food and Agricultural Sciences, University of Florida. Revised January 2003. Please visit the EDIS Web site at http://edis.ifas.ufl.edu.

2. A. R. Blount, assistant professor; D. L. Wright, professor; R. K. Sprenkel, professor; T. D. Hewitt, professor, North Florida Research and Education Center, Quincy FL; C. K. Hiebsch, associate professor, Agronomy Department; and R. O. Myer, professor, North Florida Research and Education Center, Quincy, FL; Florida Cooperative Extension Service, Institute of Food and Agricultural Sciences. University of Florida, Gainesville, FL, 32611.

The use of trade names in this publication is solely for the purpose of providing specific information. UF/IFAS does not guarantee or warranty the products named, and references to them in this publication does not signify our approval to the exclusion of other products of suitable composition.

The Institute of Food and Agricultural Sciences is an equal opportunity/affirmative action employer authorized to provide research, educational information and other services only to individuals and institutions that function without regard to race, color, sex, age, handicap, or national origin. For information on obtaining other extension publications, contact your county Cooperative Extension Service office. Florida Cooperative Extension Service/Institute of Food and Agricultural Sciences/University of Florida/Christine Taylor Waddill, Dean. 
digestible energy material per acre increase after flower until near maturity (Table 1). From the standpoint of producing the highest quantity and quality of forage, the best time to cut is at 90 percent pod fill, just before the leaves begin to yellow and fall. One of the main advantages of soybean forage is the flexibility of harvest dates, since its quality is good over a long period. Tonnage, however, is sacrificed when harvested early.

The soybean plant maintains its high quality over such an extended period because of the high protein and energy contents of the developing seed. The mature seed has about 40 percent protein and 20 percent oil. When the seeds reach about 90 percent pod fill prior to leaf drop, about one-third of the plant weight is in the seed. As the seeds develop, they more than compensate for the loss in quality in the stem and other plant parts.

In production of soybean hay there is a trade-off between tonnage and the speed at which the hay dries. When the pod is at full size and the seed is still small, a hay conditioner may be used to crush the stems and reduce the drying time. Minimal handling of the forage will reduce loss due to shattering. Consider tedding hay earlier in the day when moisture in the plant is sufficient to reduce leaf loss. With good drying conditions, drying time for conditioned hay is about two to three days. When the seed are larger, the conditioner may crush or pop the seed out of the pod. At this point, conditioning soybeans is not practical and drying time is greatly increased due to the size of the seed. Soybeans with full-sized seeds that have not been conditioned may take four to six days to cure properly.

Some soybean hay components may not be readily eaten by the animal. Losses due to refusal may range from 0 to $20 \%$. When the whole plant is ground, animals eat it readily, but this is not considered to be an economically viable practice.

\section{Soybean Silage}

When producing silage from soybean, water retention in the seed is not a problem and the lower palatability of the stems is solved by chopping and the subsequent fermentation process. The best stage to harvest soybeans for silage is near maturity before any leaf loss. At this point, however, soluble carbohydrates required for proper ensiling are low. When ensiled alone, soybean silage has an unpleasant odor and emits free ammonia and butyric acid, which are characteristics of undesirable ensiling fermentation. For proper fermentation to occur with soybean silage, a source of soluble, readily fermentable carbohydrates, like ground corn grain or molasses, should be added. A minimum of $10 \%$ of the total silage on a dry matter basis should be from these carbohydrate sources. Another option is to blend with corn or sorghum silage (i.e., 50:50). Excellent quality silage has been made from intercropped sorghum and soybean forage, from layering sorghum and soybean forage harvested from different fields, and from corn grain or ground ear corn mixed with the soybean forage.

\section{Variety Selection}

As with soybeans grown for grain, the highest forage yields are obtained from planting full season soybean varieties (Maturity Groups 6, 7, or 8) from May 10 to June 15 . Maturity group is important to consider because it indicates photoperiod response. The beginning of the reproductive period with flowering and the date of maturation are affected by the length of day much more than by the actual age of the plant. Varieties differ in their response to day length. Varieties selected for hay production require matching the expected optimum growth stage with the highest probability of dry weather. Drier periods are more common in late spring and in October. For June harvest, early Maturity Groups 4 and early 5's planted in March are probably the best choice. For an October harvest, Maturity Groups 8 and 9 varieties, planted in June, are probably best. For silage production it is not so important to match growth stage and dry weather, therefore, selection of varieties are less critical.

Nematode resistance and forage yield performance data are very important for variety selection. To reduce the stem size, high plant populations (1.5 to $2.0 \mathrm{bu} / \mathrm{acre}$ ) should be drilled or planted in narrow rows. Conventional or no-till planting should be followed. Appropriate soybean inoculants need to be applied to the seed prior to planting in fields not previously planted to soybean. 
Apply inoculant using a sticker and limit exposing the inoculated seed to sunlight.

For the last several years the Florida soybean breeding program has concentrated on the development of the long-juvenile trait in soybean. This trait is a single recessive gene that allows soybeans to have a similar period of vegetative growth regardless of planting date. This gene has been incorporated into soybean lines that have resistance to multiple pests. The resulting lines exhibit excellent agronomic performance as well as the ability to be planted over a broad range of planting dates. For example, in North Florida the long juvenile soybeans can be planted from April to July with a minimal effect on yield ability. When the long-juvenile soybean is planted in July, following corn, the soybean will remain vegetative throughout the summer and flower in late August or September. Beginning pod stage will occur in October, during the driest month of the year, when a window of opportunity exists to harvest soybeans for hay. Hinson long-juvenile soybean was released by the University of Florida in 2001 and is a well adapted forage soybean variety for grazing, hay or silage production. It has good resistance to southern root-knot nematode and to pod and stem blight. It is presently being used by dairy and beef cattle producers, and to a limited extent, by wildlife enthusiasts. Seed of this variety are available by contacting the Florida Foundation Seed Producers, Inc., Greenwood, FL.

\section{Weed Control}

There are fewer control measures for weeds in forage than in grain soybean production. Many herbicides have restrictions for use over the top of soybeans when grazed or used for forage. To have limited weed problems, fields with low weed pressure should be selected and pre-emergent herbicides should be used to control weeds until the crop canopy shades the weeds. The high population and narrow rows will greatly aid in weed control.

Additional information is available at: http://edis.ifas.ufl.edu/

TOPIC_GUIDE_Weed_Management_Guide

\section{Insect Pests}

There are several obstacles to managing insect pests on soybeans grown for grazing, hay or silage. Foremost among these problems is the small number of registered insecticides that permit the use of the crop for grazing or hay following application. Of the insecticides registered for use on soybeans grown for forage or grazing, pre-harvest intervals range from 3 to 20 days. This means that, for a number of insecticides, treatments could not be made just prior to harvesting for hay at the pod fill stage. This is a period in the development of soybeans when they are highly attractive to a number of insect pests, including stink bugs and corn earworms.

Table 2 gives the common names of the active ingredients and an example of a registered product for soybeans that are to be grazed, or cut for hay or silage. Suggested use rates for the commonly-encountered insect pests on soybeans in Florida are also given. Remember to read all pesticide labels carefully and follow label recommendations.

Carbaryl (Sevin 4F) may be used on soybeans to within 14 days of grazing or being cut for hay. It may be used up to four times per season but not more than once every seven days.

Diflubenzuron (Dimilin 2L) is a Restricted Use Insecticide that may be used to within 21 days of harvest. A maximum of two applications may be made per season.

Dimethoate (Dimethoate 4EC) has the shortest pre-harvest interval of any of the insecticides registered for use on soybeans that are to be grazed or cut for forage. Dimethoate may be used to within 5 days of feeding or grazing.

Methomyl (Lannate LV) is a Restricted Use Insecticide that may be used to within 3 days of harvest as forage and 12 days of cutting for hay.

Methyl parathion (Declare 4EC) is a Restricted Use Insecticide that has a pre-grazing interval of 20 days.

For additional information, see EDIS publication ENY-405 "Insect Management in Soybeans" (http://edis.ifas.ufl.edu/IG064) 


\section{Ecomonics of Soybean Forage}

Soybeans may be grown for use as high-protein forage with quality similar to alfalfa. When harvested at maximum dry matter per acre (when seeds are nearly full size and leaves have not begun to fall), the weight of the dry forage is about 3 times the mature seed. Therefore, a $30 \mathrm{bu} / \mathrm{acre}$ grain crop would yield about 2.7 tons/acre of dry forage. Yield trials at the North Florida Research and Education Center at Quincy have averaged around 3 tons/acre dry matter from June and July plantings. At $\$ 100 /$ ton for dry forage and $\$ 6 /$ bu for soybeans (current price is near $\$ 5.00 / \mathrm{bu}$ ), an acre is worth about $50 \%$ more as a forage crop.

\section{Summary}

Soybeans may be grown for use as a high-protein forage for grazing, haying or ensiling. Adapted varieties should provide a forage with qualities similar to alfalfa. Inexpensive seed makes this summer legume an excellent choice for livestock and wildlife. Concerns about weed and pest control measures should be minimized with careful management of this forage as outlined in this publication. For further information on recommended soybean varieties contact your local Extension Office. 
Table 1. Effect of harvest date on soybean forage quality and quantity.

\begin{tabular}{|c|c|c|c|c|c|c|c|c|c|}
\hline \multirow{2}{*}{$\begin{array}{c}\text { Days } \\
\text { of } \\
\text { age }\end{array}$} & \multirow{2}{*}{$\begin{array}{l}\text { Growth } \\
\text { stage }\end{array}$} & \multicolumn{2}{|c|}{ Dry matter yield } & \multicolumn{2}{|c|}{ Crude protein } & \multirow{2}{*}{$\begin{array}{c}\text { Fat } \\
\text { \%DM }\end{array}$} & \multirow{2}{*}{$\begin{array}{l}\text { NDF } \\
\text { \%DM }\end{array}$} & \multicolumn{2}{|c|}{ IVDOM $^{*}$} \\
\hline & & \%DM & Ib/acre & \%DM & lb/acre & & & \%DM & Ib/acre \\
\hline 75 & $50 \%$ bloom & 24 & 3664 & 17.8 & $64 /$ & 2.1 & 54.5 & 59.0 & 2162 \\
\hline 82 & $75 \%$ bloom & 27 & 4000 & 17.0 & 675 & 2.2 & 53.9 & 58.2 & 2328 \\
\hline 89 & $95 \%$ bloom & 27 & 4501 & 16.7 & 749 & 2.4 & 56.7 & 59.8 & 2692 \\
\hline 96 & Pods .5 full & 26 & 5216 & 18.4 & 960 & 2.9 & 50.8 & 60.3 & 3145 \\
\hline 103 & Pods .66 full & 26 & 5061 & 19.4 & 982 & 3.7 & 50.2 & 61.4 & 3107 \\
\hline 110 & Pods .75 full & 26 & 5520 & 20.8 & 1147 & 5.4 & 48.9 & 60.2 & 3323 \\
\hline 117 & Pods .90 full & 27 & 7105 & 20.9 & 1483 & 6.2 & 46.6 & 60.8 & 4320 \\
\hline 124 & $30 \%$ leaf drop & 29 & 6129 & 21.3 & 1307 & 7.4 & 43.0 & 61.0 & 3738 \\
\hline 131 & $85 \%$ leaf drop & 35 & 5789 & 22.3 & 1293 & 8.5 & 43.9 & 60.3 & 3490 \\
\hline 138 & $100 \%$ leaf drop & 56 & 4357 & 24.6 & 1072 & 9.2 & 41.9 & 60.0 & 2614 \\
\hline
\end{tabular}

Table 2. Insecticides registered for use on soybeans that are to be grazed or cut for hay or silage.

\begin{tabular}{|c|c|c|c|c|c|}
\hline \multirow[t]{2}{*}{ Pest } & $\begin{array}{l}\text { carbaryl } \\
\text { (Sevin 4F) }\end{array}$ & $\begin{array}{l}\text { diflubenzuron } \\
\text { (Dimilin 2L) }\end{array}$ & $\begin{array}{c}\text { dimethoate } \\
\text { (Dimethoate 4EC) }\end{array}$ & $\begin{array}{c}\text { methomyl } \\
\text { (Lannate LV) }\end{array}$ & $\begin{array}{l}\text { methyl parathion } \\
\text { (Declare 4EC) }\end{array}$ \\
\hline & \multicolumn{5}{|c|}{-- Rate Formulation/Acre ----- } \\
\hline Bean leaf beetle & $-1 \mathrm{qt}$ & -- & $1 \mathrm{pt}$ & $3 / 4-11 / 2 \mathrm{pt}$ & $2 \mathrm{pt}$ \\
\hline Beet armyworm & -- & $4 \mathrm{oz}$ & -- & $3 / 4-11 / 2 p t$ & -- \\
\hline Blister beetle & $1 / 2-1 q t$ & -- & -- & -- & $3 / 4-2 p t$ \\
\hline Corn earworm & $1 / 2-1 \quad 1 / 2 q t$ & -- & -- & $3 / 4-11 / 2 p t$ & $2 \mathrm{pt}$ \\
\hline Grasshoppers & -- & $20 z$ & $1 \mathrm{pt}$ & -- & $2 \mathrm{pt}$ \\
\hline $\begin{array}{c}\text { Green } \\
\text { cloverworm }\end{array}$ & $1 / 2-1 \mathrm{qt}$ & $2-4 \mathrm{oz}$ & $\overline{--}$ & $3 / 4-11 / 2 \mathrm{pt}$ & $1-2 \mathrm{pt}$ \\
\hline $\begin{array}{l}\text { Saltmarsh } \\
\text { caterpillar }\end{array}$ & $11 / 2$ qt. & -- & -- & $3 / 4-11 / 2 \mathrm{pt}$ & -- \\
\hline Soybean looper & -- & $\begin{array}{c}4 \mathrm{oz} \\
\text { suppression }\end{array}$ & -- & -- & -- \\
\hline Stink bug & $1-11 / 2 q t$ & -- & -- & -- & $3 / 4-2 p t$ \\
\hline $\begin{array}{l}\text { Three cornered } \\
\text { alfalfa hopper }\end{array}$ & $1 \mathrm{qt}$ & -- & $1 \mathrm{pt}$ & -- & $3 / 4-2 p t$ \\
\hline $\begin{array}{c}\text { Two-spotted } \\
\text { spider mite }\end{array}$ & -- & -- & $1 \mathrm{pt}$ & -- & $3 / 4-2 p t$ \\
\hline $\begin{array}{l}\text { Velvetbean } \\
\text { caterpillar }\end{array}$ & $1 / 2-1 q t$ & $2-4 o z$ & -- & $3 / 4-1 \quad 1 / 2 \mathrm{pt}$ & $3 / 4-2 p t$ \\
\hline
\end{tabular}

